\title{
Method for the Rapid Determination of Acetic and Higher Acids in Cigarette Smoke*
}

\author{
by Gerald P. Morie \\ Research Laboratories, Tennessee Eastman Company, Division of Eastman Kodak Company, \\ Kingsport, Tennessee, USA
}

\section{INTRODUCTION}

The determination of aliphatic acids in cigarette smoke has been the subject of a number of papers. Titrations, both in aqueous and nonaqueous media, have been used successfully for a measure of total acidity $(1,2)$. However, titrations in aqueous media are not completely accurate because of the hydrolysis of esters, although the error is probably relatively small. Cundiff, Sensabaugh, and Markunas titrated strong, weak, and very weak acids present in smoke using pyridine as a differentiating solvent (3). This method overcomes the hydrolysis of esters but does not distinguish the individual acids.

Several gas chromatographic methods for the determination of acids in cigarette smoke exist $(4,5,6)$. However, these methods either require conversion of the acids to the methyl esters or involve steam distillation, extraction into strong base, or some other pretreatment prior to the chromatographic determination. In a novel method described by Oakley, Weissbecker, and Resnik (7), the methyl esters of acetic and formic acids are formed on an anion exchange column in the fluoride form. The resulting esters are then separated and determined by gas chromatography. In general, it seemed that the existing methods for the determination of acids were either too time consuming, nonspecific, or imprecise. The method described in this paper is specific, rapid, and simple. It involves extraction of the aliphatic acids into a weakly basic buffer, followed by a separation and determination of the free acids by gas chromatography.

\section{EXPERIMENTAL}

\section{Apparatus}

A Varian Model 1860 gas chromatograph equipped with a flame detector and a Honeywell Model 194 I-mV recorder was used. A Phipps and Bird automatic smoking machine (Phipps and Bird Inc., Richmond, Va.), a Filtrona Model 200 smoking machine (Cigarette Components Ltd., London, England), and a single port smoking machine of our design were used for smoking cigarettes. A Packard 3002 Tri-Carb liquid scintillation spectrometer was used to check the extraction of $\mathrm{C}^{14}$ labeled acetic acid.

" Presented at the 24th Tobacco Chemists' Research Conference, Montreal, Quebec, October 28-30, 1970.

\section{Reagents}

Known solutions of aliphatic acids were prepared from Eastman reagent-grade acids (Eastman Kodak Co., Rochester, N. Y.). Sodium borate buffer solutions were prepared from boric acid (Baker and Adamson, Div. of Allied Chemical Co., Morristown, N. J.) and sodium hydroxide. Reagent-grade carbon disulfide (Baker and Adamson) was used for extracting the total particulate matter (TPM) from the Cambridge filters.

Chromosorb 101, a porous polymer gas chromatographic packing (Johns-Manville, New York, N. Y.), was selected for all chromatographic separations.

\section{Extraction Studies}

In order to determine if acetic acid is extracted quantitatively into a $\mathrm{pH} 8.0$ buffer, distribution studies with $C^{14}$-labeled acetic acid were employed. Labeled acetic acid (200- $\mu$ l portions with a specific activity of $23.6 \mu \mathrm{Ci} /$ $\mathrm{ml})$ was added to three vials, each of which contained $50 \mathrm{ml}$ of $\mathrm{CS}_{2}$ and a Cambridge filter pad with the TPM from five cigarettes. Ten milliliters of aqueous sodium borate buffer were added, and the vials were agitated on a shaker for $10 \mathrm{~min}$. Two-hundred microliter portions of both phases were added to liquid scintillation solutions, and the distribution ratio (D) was calculated from the following formula:

$$
\mathrm{D}=\frac{(\text { activity })_{\mathrm{aq}}}{\text { (activity) } \mathrm{CS}_{\mathbf{2}}} \text {. }
$$

The percent extraction $(E)$ is given as:

$$
E, \%=\frac{100 \mathrm{D}}{\mathrm{D}+\mathrm{V}_{\mathrm{aq}} / \mathrm{VCS}_{2}} \text {. }
$$

\section{Possible Interferences from Esters}

To determine if the $\mathrm{pH}$ was high enough to hydrolyze esters in the smoke condensate samples, the following tests were made. Aqueous buffer and carbon disulfide were added to four extraction vials. Five milligrams of methyl acetate were added to two of the vials, and $5 \mathrm{mg}$ of triacetin were added to the two remaining vials. The vials were shaken for $10 \mathrm{~min}$. and allowed to stand at room temperature. At 30-min. intervals, $5-\mu$ l aliquots of the buffer were sampled and injected onto the gas chromatographic column. The chromatographic conditions and determination of acetic acid are described in the following section. 


\section{Analytical Procedures}

Cigarettes were smoked under standard conditions (35-ml puffs of 2-sec. duration at 1-min. intervals) to a $27-\mathrm{mm}$ butt length. The particulate matter was collected on a Cambridge filter pad, and the small amounts of acids not trapped by this filter were collected in a scrubber containing $50 \mathrm{ml}$ of carbon disulfide. Four to five cigarettes were smoked in succession, and the same filter and scrubber solution were used for each.

The carbon disulfide originally in the scrubber and the Cambridge filter were then added to a 4-oz bottle equipped with a Poly-Cone seal screw-cap lid. Then, $10 \mathrm{ml}$ of a $0.01 \mathrm{M}$ sodium borate buffer $(\mathrm{pH} \mathrm{8.0)}$ were pipetted into the vial. When only acetic acid was determined, the buffer also contained butyric acid as an internal standard. The mixture was agitated on a Burrel wrist-action shaker for $10 \mathrm{~min}$; after the two phases had separated, a 3- to 5- $\mu$ l aliquot of the aqueous phase was sampled with a $10-\mu$ l syringe and injected onto the gas chromatographic column. The following chromatographic conditions were used:

Column: 4 -ft. $\times 1 / 4$-in. OD glass, packed with Chromosorb 101 column packing

Column temperature: $175^{\circ} \mathrm{C}$

Injection port temperature: $200^{\circ} \mathrm{C}$

Detector temperature: $200^{\circ} \mathrm{C}$

Carrier gas: helium

Flow rate: $35 \mathrm{ml} / \mathrm{min}$.

Detector: flame, set at $10^{-11} \mathrm{amp} . / \mu \mathrm{V}$

Calibration curves based on peak height were constructed for acetic, propionic, butyric, isobutyric, valeric, and hexanoic acids. When only acetic acid was determined, it was useful to employ butyric acid as an internal standard.

\section{RESULTS AND DISCUSSION}

\section{Extraction of Aliphatic Acids.}

To separate the aliphatic acids from many of the other volatile compounds in cigarette smoke, an extraction from carbon disulfide into a weakly basic, aqueous solution was employed. Nearly any organic solvent used to dissolve the TPM would be extracted into the aqueous phase to a small extent. Carbon disulfide was selected because the small amount which is extracted into the aqueous buffer does not give a response in the flame detector of the gas chromatograph. The $\mathrm{pH}$ of the aqueous buffer is critical for the following reasons: the $\mathrm{pH}$ should be sufficiently high to allow the complete extraction of the aliphatic acids, but it should not be so high that hydrolysis of esters occurs. At a $\mathrm{pH}$ of 8.0 the ratio of undissociated (A-) to dissociated (HA) acetic acid is I700:I $\left(\frac{K_{a}}{\left(\mathrm{H}^{+}\right)}=\frac{(\mathrm{A}-)}{(\mathrm{HA})}=\frac{1700}{I}\right)$.

Therefore, extraction into an aqueous phase is favorable. The acidity constants $\left(K_{a}\right)$ of other aliphatic acids are similar to the acidity constant of acetic acid. Therefore, this ratio is similar in magnitude to the ratios for other aliphatic acids.
The extraction of acetic acid into the buffer is nearly quantitative. The distribution ratio, determined with $\mathrm{C}^{14}$-labeled acetic acid, is 432 ; and the percent extraction is 98.9.

No detectable amount of either triacetin or methyl acetate hydrolyzed to acetic acid in $2 \mathrm{hr}$. or less. After 2 hr., a trace of acetic acid appeared in the chromatogram; after $4 \mathrm{hr}$., enough acetic acid was produced to cause an appreciable error in the method.

\section{Gas Chromatographic Separations of Aliphatic Acids}

The chromatographic separation of acetic acid and butyric acid, which was added as an internal standard, is shown in Figure 1. The separation is rapid, and peaks exhibit very little tailing. Chromosorb IoI column packing was chosen because of its hydrophobicity, and its ability to separate polar compounds. The properties of this and other porous polymer packings were recently reviewed by Dave (8).

Figure 1. Gas chromatogram of acetic acid and butyric acid.

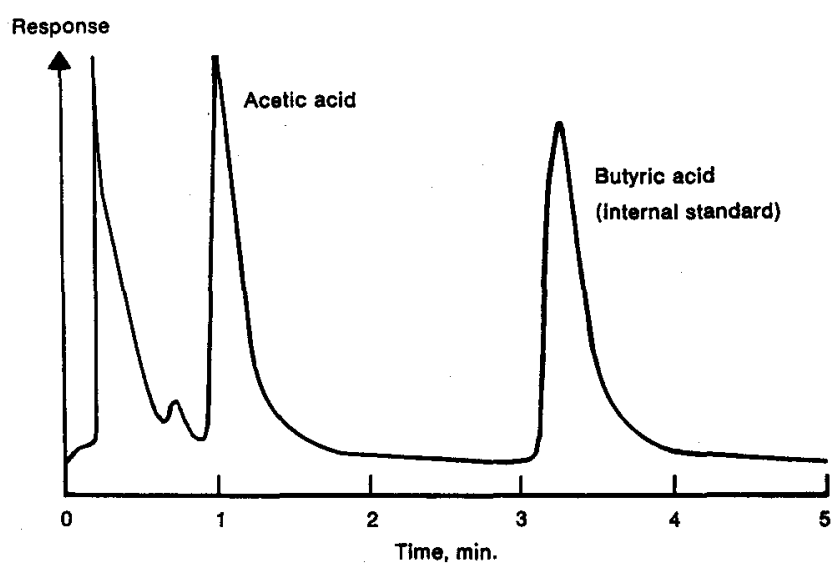

Butyric acid, a substance which is present in cigarette smoke, was used as an internal standard. This is permissible because of the relatively small amount present in smoke. For example, there is only about $3 \%$ as much butyric acid as there is acetic acid in cigarette smoke. Therefore, even a $50 \%$ variation in the level of butyric acid in smoke would cause only a $1.5 \%$ error in the acetic acid results.

"Ghosting" has long been a problem in the gas chromatography of polar compounds, especially acids. This phenomenon, the irreversible adsorption of certain compounds and the subsequent re-elution of these compounds by the solvent or other polar compounds, has been the subject of several papers $(9,10)$. Geddes and Gilmour found that the addition of formic acid

Table 1. Etfect of formic acid on ghosting of acetic acid.

\begin{tabular}{l|c|c|c}
\cline { 2 - 4 } & $\begin{array}{c}\text { Number of } \\
\text { injections } \\
\text { of acetic } \\
\text { acid* }\end{array}$ & $\begin{array}{c}|c| \\
\text { Ghosting after } \\
\text { injection of buffer, \%** } \\
\text { 1st }\end{array}$ & 2nd \\
\hline Formic acid absent & 5 & 28 & 13 \\
Formic acid present & 5 & 3 & 1 \\
\hline
\end{tabular}

* $2 \mu$ l of solution, $0.2 \mathrm{mg}$ acetic/ml of solution.

** 2 ul of buffer. 
to a solution of fatty acids nearly eliminated ghosting of the higher acids and increased the precision of the analysis (10). This explains why ghosting was never observed in actual smoke samples, which contain formic acid, but was observed in known samples. Therefore, formic acid $(0.05 \mathrm{mg} / \mathrm{ml})$ was added to known solutions, and the results are given in Table 1 . It is postulated that formic acid is adsorbed on the support in preference to acetic acid.

The precision of the method was calculated with a series of ten samples. Each sample consisted of the smoke from five nonfilter domestic blend cigarettes. A standard deviation of $15 \mu \mathrm{g}$ of acetic acid was obtained for an average of $396 \mu \mathrm{g}$; the coefficient of variation was $3.8 \%$.

To measure the accuracy of the method, samples of smoke condensate were analyzed according to the procedure described previously. Known additions of acetic acid were made and the vials were reequilibrated for to min. The aqueous layer was again sampled and the amount of acetic acid found was compared with the amount added. The recovery was good; $419 \mu \mathrm{g}$ of acetic acid were found in a sample which should have contained $438 \mu \mathrm{g}$, and $725 \mu \mathrm{g}$ were found in a sample to which $715 \mu \mathrm{g}$ had been added.

It was somewhat surprising that the aliphatic acids could be chromatographed reproducibly after the salts of the acids were injected onto the chromatographic column. Initially, the aqueous buffer was acidified before an aliquot was injected onto the column, but this step was found to be unnecessary. Apparently, the acids are released from their salts at temperatures of $200^{\circ} \mathrm{C}$.

During the development of this method, it was found that approximately $98 \%$ of the acetic acid present in cigarette smoke is trapped on a Cambridge filter. This value agrees with that obtained by other workers $(6,7)$. Therefore, for many applications, it would be permissible to collect acetic acid from cigarette smoke on a Cambridge filter.

Table 2. Amount of acetic acld delivered by various brands of cigarettes.

\begin{tabular}{c|c|l|c}
\hline Brand & Length, mm & Filter & $\begin{array}{c}\text { Acetic acid } \\
\text { delivered, } \mu \mathrm{g} / \mathrm{cig}\end{array}$ \\
\hline A & 85 & None & 370 \\
B & 85 & Acetate & 241 \\
C & 85 & Acetate & 290 \\
D & 85 & Acetate & 218 \\
E & 85 & Acetate/carbon & 205 \\
F & 100 & Acetate & 287 \\
\hline
\end{tabular}

The amounts of acetic acid delivered by various brands of domestic cigarettes are shown in Table 2. The amount of acetic acid delivered per cigarette is considerably less than the amount reported by Buyske and co-workers (I). Conversely, most of these values are higher than those reported by Oakley, Weissbecker, and Resnik (7).

To compare this method with those reported previously
Table 3. Amount of acetic acid dellvered by Burley and Bright tobacco clgarettes.

\begin{tabular}{l|c|c|c}
\hline $\begin{array}{c}\text { Type } \\
\text { cigarette }\end{array}$ & \multicolumn{2}{|c|}{ Amount of acetic acid, $\mu \mathrm{g} / \mathrm{cig}}$. & $\begin{array}{c}\text { Oakley } \\
\text { et al. (7) }\end{array}$ \\
& This method & $\begin{array}{c}\text { Buyske } \\
\text { et al. (1) }\end{array}$ & \\
\hline Burley & 278 & 864 & 235 \\
Bright & 620 & 1032 & 437 \\
\hline
\end{tabular}

$(1,7)$, acetic acid was determined in the smoke from 70-mm cigarettes made from all-Burley and/or allBright tobacco. The results are given in Table 3 and are listed with previous values for comparison. These values cannot be compared directly with those for domestic blend cigarettes because of differences in cigarette weight, casing agents, and paper porosity.

The removal of acetic acid by various filters is given in Table 4. The tobacco butt also removes acetic acid; therefore, the values were calculated by comparing the results for filter cigarettes with those for similar cigarettes having a 20-mm plastic tube in place of a filter. In this way, it was possible to obtain the removal value for a $20-\mathrm{mm}$ section of tobacco. A filter similar to that on several popular brands of cigarettes removed about $50 \%$ of the acetic acid. The selectivity of the filters for acetic acid was calculated using the system of Davis and George (11).

The selectivity coefficient for the removal of acetic acid by the cellulose acetate filters was 1.20, whereas that for the paper filters was 1.07; thus, acetate filters are more selective than paper filters for removing acetic acid. Activated carbon, triethanolamine, and potassium bicarbonate enhanced the capacity of the acetate filters for removing acetic acid from cigarette smoke. A recent study on the selectivity of filters for aliphatic acids, gave inconclusive results owing to the variability of the method employed (12).

Table 4. Removal of acetic acid by fitters and filter additives.

\begin{tabular}{l|l|c|c|c|c}
\hline \multicolumn{1}{c|}{ Filter } & $\begin{array}{c}\text { Filter } \\
\text { additives }\end{array}$ & $\begin{array}{c}\text { Acetic } \\
\text { acid, } \\
\mu \mathrm{g} / \\
\text { cig. }\end{array}$ & $\begin{array}{c}\text { Acetic } \\
\text { acid } \\
\text { re- } \\
\text { moval, } \\
\% \%\end{array}$ & $\begin{array}{c}\text { TPM } \\
\text { re- } \\
\text { moval, } \\
\%\end{array}$ & $\begin{array}{c}\text { Selec- } \\
\text { tivity }\end{array}$ \\
\hline None, $20 \mathrm{~mm}$ tube & None & 615 & - & - & - \\
Tobacco & None & 376 & 39 & - & - \\
Acetate, $20 \mathrm{~mm}$ & None & 305 & 51 & 41 & 1.20 \\
Paper, $20 \mathrm{~mm}$ & None & 230 & 62 & 59 & 1.07 \\
Acetate, $20 \mathrm{~mm}$ & Carbon & 244 & 60 & 39 & 1.52 \\
Acetate, $20 \mathrm{~mm}$ & TEA* & 170 & 72 & 41 & 2.10 \\
Acetate, $20 \mathrm{~mm}$ & KHCO 3 & 195 & 68 & 40 & 1.88 \\
\hline
\end{tabular}

* Triethanolamine.

Figure 2 illustrates the chromatographic separation of acetic, propionic, isobutyric, butyric, isovaleric, valeric, and hexanoic acids. The smoke particulate matter from 20 cigarettes was extracted from $100 \mathrm{ml}$ of carbon disulfide into $10 \mathrm{ml}$ of buffer, and a $5-\mu l$ portion of the extract was injected onto the column. The individual peaks were identified by their retention times. 
Figure 2. Gas chromatogram of acetic acid through hexanolc acid.

Response

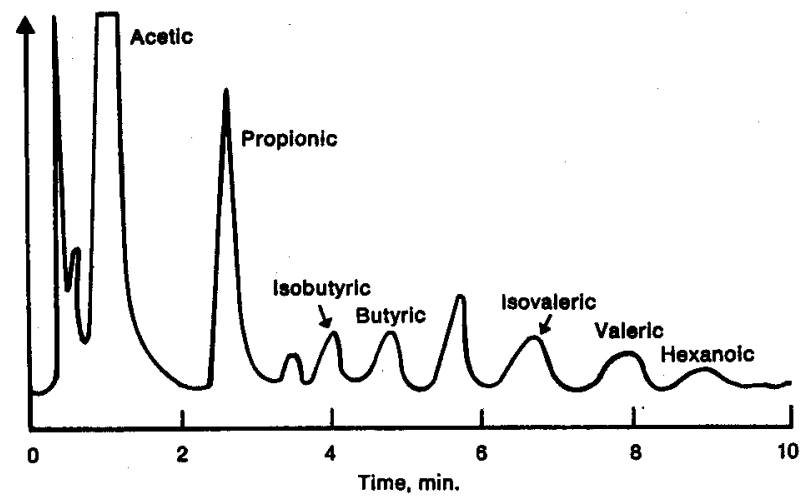

The amounts of propionic, butyric, isobutyric, and isovaleric acids present in the smoke from several types of cigarettes are shown in Table 5. Compared to the amount of acetic acid found, very small amounts of the higher acids were found. Formic acid gives little or no response in a flame detector and was therefore not included in the analysis.

Table 5. Amount of acids delivered by various cigarettes.

\begin{tabular}{|c|c|c|c|c|c|}
\hline \multirow[b]{2}{*}{ Sample } & \multirow[b]{2}{*}{ Filter } & \multicolumn{4}{|c|}{ Acids delivered, $\mu \mathrm{g} / \mathrm{cig}$. } \\
\hline & & $\begin{array}{l}\text { Pro- } \\
\text { pionic }\end{array}$ & Butyric & $\begin{array}{c}\text { Iso- } \\
\text { butyric }\end{array}$ & $\begin{array}{l}\text { Iso- } \\
\text { valeric }\end{array}$ \\
\hline $\begin{array}{l}\text { Turkish, } \\
70 \mathrm{~mm}\end{array}$ & None & 40 & 18 & 16 & 28 \\
\hline $\begin{array}{l}\text { Bright, } \\
70 \mathrm{~mm}\end{array}$ & None & 61 & 17 & 10 & 14 \\
\hline $\begin{array}{l}\text { Domestic } \\
\text { blend, } 70 \mathrm{~mm}\end{array}$ & None & 32 & 12 & 10 & 10 \\
\hline $\begin{array}{l}\text { Domestic } \\
\text { blend, } 65 \mathrm{~mm}\end{array}$ & $\begin{array}{l}\text { Acetate, } \\
20 \mathrm{~mm}\end{array}$ & 17 & 10 & 8 & 10 \\
\hline
\end{tabular}

The analytical method described is simple, rapid, and precise; and it does not cause the hydrolysis of esters. Acetic acid in a smoke sample can be determined in 15 to $20 \mathrm{~min}$. with a coefficient of variation of $4 \%$. The method shows that cellulose acetate filters selectively remove acetic acid from cigarette smoke and that certain filter additives can enhance this property considerably.

\section{SUMMARY}

A method for the rapid determination of acetic and higher aliphatic acids in cigarette smoke is described. Cigarette smoke is collected on a Cambridge filter, which is followed by a carbon disulfide scrubber. The total particulate matter (TPM) on the Cambridge filter is dissolved in carbon disulfide, and the acids are then extracted from this solution into an aqueous sodium borate solution ( $\mathrm{pH} \mathrm{8)}$. An aliquot of this extract is injected onto a gas chromatographic column containing Chromosorb 101 column packing. The determination of acetic acid requires the smoke of 5 cigarettes and is completed in $15 \mathrm{~min}$. (10 min. for extraction and 5 min. for chromatographic separation). The coefficient of variation of the method is $3.8 \%$. The determination of acetic through hexanoic acid requires the smoke of 20 cigarettes and is completed in $20 \mathrm{~min}$. The amounts of acetic acid delivered from cigarettes of various types were determined. Commercial cellulose acetate filters removed a slightly higher percentage of acetic acid than dry TPM from the smoke of a domestic cigarette.

\section{ZUSAMMENFASSUNG}

Es wird eine Methode zur schnellen Bestimmung von Essigsäure und höheren aliphatischen Säuren in Cigarettenrauch beschrieben. Der Rauch wird in einem System aus einem Cambridge-Filter und nachgeschalteter Waschflasche mit Schwefelkohlenstoff niedergeschlagen. Das Gesamtkondensat (TPM) vom Cambridge-Filter wird in Schwefelkohlenstoff gelöst, und die Säuren werden daraus mit einer wässerigen Natriumboratlösung ( $\mathrm{pH}$ 8) extrahiert. Ein aliquoter Teil des Extraktes wird auf eine Gaschromatographie-Säule mit Chromosorb 10I gegeben. Die Bestimmung von Essigsäure erfordert den Rauch von fünf Cigaretten und dauert 15 Minuten (1o Minuten Extraktion, 5 Minuten chromatographische Trennung). Der Variationskoeffizient der Methode beträgt 3,8\%. Die Bestimmung der Verbindungen von der Essigsäure bis zur Capronsäure erfordert den Rauch von zwanzig Cigaretten und dauert 20 Minuten. Die Bestimmung der Essigsäure wurde bei verschiedenen Cigarettenarten durchgeführt. Handelsübliche Celluloseacetatfilter amerikanischer Cigaretten retinieren einen geringfügig höheren Prozentsatz an Essigsäure im Vergleich zum Gesamtkondensat.

\section{RESUME}

On décrit une méthode pour la détermination rapide des acides acétiques et supérieurs dans la fumée de cigarettes. On récupère la fumée sur un filtre Cambridge, auquel succède un éluant au disulfure de carbone. La matière particulaire totale (TPM) est dissoute sur le filtre Cambridge par le disulfure de carbone, et on extrait ensuite les acides de cette solution par une solution aqueuse au borate de sodium ( $\mathrm{pH} 8$ ). On injecte une dose de cet extrait dans une colonne chromatographique à phase gazeuse contenant du Chromosorb 101. On a besoin de 5 cigarettes pour la détermination de l'acide acétique et celle-ci est terminée en $15 \mathrm{~min}$. (10 min. pour l'extraction et $5 \mathrm{~min}$. pour la séparation chromatographique). Le coëfficient de variation de la méthode est de $3,8 \%$. La détermination de l'acide acétique par l'acide hexanoïque nécessite la fumée de 20 cigarettes et est achevée en $20 \mathrm{~min}$. On a déterminé les quantités d'acide acétique libéré par des cigarettes de variétés différentes. Les filtres commerciaux en acétate de cellulose éliminent de la fumée de cigarettes locales un pourcentage légèrement plus élevé en acide acétique qu'en TPM sèche. 


\section{REFERENCES}

I. Buyske, D. A., Pelham, W., and Hobbs, M. E.: Anal. Chem. 29 (1957) 105.

2. British-American Tobacco Company, Germany, Private communication (1970).

3. Cundiff, R. H., Sensabaugh, A. J., and Markunes, P. C.: Tob. Sci. 2 (1958) 25.

4. Stedman, R. L., Burdick, D., and Schmeltz, I.: Tob. Sci. 7 (1963) 166.

5. Mahnachev, I., Serdyuk, L., and Ivanov, N.: CR Acad. Bulg. Sci. 20 (1.967) 445.

6. Kaburaki, Y., Mikami, Y., and Nakamura, M.: Jap. Monop. Corp. Cent. Res. Inst. Sci. Pap. III (1969) $15 x$.

7. Oakley, E. T., Weissbedker, L., and Resnik, F. E.: Anal. Chem. 37 (1965) 380.

8. Dave, S. B.: J. Chromatogr. Sci. 7 (1969) 389.

9. Van Eenaeme, C., Lambot, O., Bienfait, J. M., and Pondant, A.: Ann. Med. Vet. 112 (1968) 181.
10. Geddes, D. A., and Gilmour, M. N.: J. Chromatogr. Sci. 8 (1970) 394.

11. Davis, H. J., and George, W. T.: Beitr. Tabakforsch. 3 (1965) 203.

12. Lakritz, L., Stedman, R. L., and Strange, E. D.: Beitr. Tabakforsch. 5 (1969) 104.

Acknowledgment

The author gratefully acknowledges the assistance of Mr. John Neal.

The author's address:

Tennessee Eastman Company, Research Laboratories, Kingsport, Tennessee, 37662, USA. 